\title{
Okul yöneticilerinin yönetici kaygı düzeylerinin yordayıcısı olarak psikolojik sermaye
}

\author{
Ahmet AVCI ${ }^{[*]}$ \\ Hasan BOZGEYIKLLí ${ }^{[* *]}$
}

\begin{abstract}
Öz
Bu araştırmanın amac1; okul yöneticilerinin sahip oldukları psikolojik sermayenin, yönetici kaygı düzeylerini anlamlı şekilde yordayıp yordamadığının tespit edilmesidir. Araştırmada tarama modeli kullanılmıştır. Araştırmanın verileri, 2016-2017 eğitim öğretim yılında, İstanbul'da Milli Eğitim Bakanlı̆̆ı’na bağlı kamu okullarında yöneticilik yapan ve basit seçkisiz örneklem yöntemiyle seçilen (\% 78,6’’sı erkek; \% 21,4’ü kadın) 345 okul yöneticisinden elde edilmiştir. Araştırmaya katılan yöneticilerin \% 71’i (245 kişi) okul müdürü; \% 29’u (100 kişi) müdür yardımcısı olarak görev yapmaktadır. Araştırma verileri "yönetici kaygı ölçeği” ve "örgütsel psikolojik sermaye ölçeği” ile toplanmıştır. Toplanan verilerin çözümlenmesinde Pearson korelasyon katsayısı ve çoklu doğrusal regresyon analizi kullanılmıştır. Araştırma sonuçları okul yöneticilerinin yönetici kaygı düzeyleri ile psikolojik sermaye ölçeğinin alt boyutları olan iyimserlik, umut, psikolojik dayanıklılık ve özyeterlik arasında negatif yönlü anlamlı bir ilişki olduğunu göstermiştir. Yordama analizleri sonucunda elde edilen bulgulara göre ise psikolojik sermaye ölçeğinin alt boyutları olan psikolojik dayanıklılık, iyimserlik ve özyeterliliğin okul yöneticilerinin yönetim kaygılarının en önemli yordayıcıları olduğu tespit edilmiştir. Araştırmadan elde edilen sonuçlar ilgili literatür çerçevesinde tartışılmış ve gelecek araştırmalara yönelik öneriler sunulmuştur.
\end{abstract}

Anahtar kelimeler: Okul yöneticileri, yönetim süreci kaygısı, psikolojik sermaye, iş yükü kaygis1.

\section{Psychological capital as a predictor of managerial anxiety levels of school administrators}

\begin{abstract}
The purpose of this research is to determine whether psychological capitals that the school administrators have significantly predict the administrator anxiety levels. Descriptive survey design

${ }^{[*]}$ Yrd. Doç. Dr., Fatih Sultan Mehmet Vakıf Üniversitesi, Eğitim Bilimleri Bölümü, aavci@fsm.edu.tr

${ }^{[* *}$ Doç. Dr., Erciyes Üniversitesi, Eğitim Fakültesi, Eğitim Bilimleri Bölümü, hbozgeyikli@erciyes.edu.tr
\end{abstract}


was used in the research. The data of the research were obtained from 345 school administrators (78.6\% male, $21.4 \%$ female) who were administrators in the schools affiliated to the Ministry of National Education in Istanbul in 2016 and were selected by simple random sampling method. $71 \%$ (245 people) of the administrators who participated in the research were school principals, and $29 \%$ (100 people) of them were vice principals. In the research, administrators' anxiety levels and the psychological capital levels of school administrators were measured by "administrator anxiety scale" and "organizational psychological capital scale," respectively. Pearson correlation technique and multiple linear regression analysis were used to analyze the collected data. The results of the research showed that there was a negative significant relationship between the administrators' anxiety levels of school administrators and their optimism, hope, psychological endurance, and self-efficacy, which are the sub-dimensions of the psychological capital scale. According to the findings obtained as a result of the predictive analyses, the psychological endurance, optimism, and self-efficacy, which are the sub-dimensions of the psychological capital scale, were found to be the most important predictors of school administrators' administrative anxieties. The results obtained from the research were discussed within the scope of the relevant literature, and proposals were made for future researches.

Keywords: School administrators, administration process anxiety, psychological capital, workload anxiety.

\section{Giriş}

Günümüzün dünyasında yaşanan bilimsel ve teknolojik gelişmeler, örgütlerin yapısında, yönetici ve çalışanların görev ve rollerinde önemli değişmeler ortaya çıkarmıştır. Sosyal yapının değişmesinde odak noktasını oluşturan eğitim örgütleri de kaçınılmaz olarak bu hızlı değişmeden payını almıştır (Kozak, 2016). Kaliteli bir eğitim-öğretim ortamının oluşturulması için bir eğitim kurumunun örgütsel kapasitenin geliştirilebilmesi ve öğrencilerin öğrenmesinin artırılmasında önemli etkenlerden birinin okul yöneticilerinin liderliği olduğu ileri sürülmektedir (Bruce King ve Bouchard, 2011; Louis, Leithwood, Wahlstrom ve Anderson, 2010). Okul lideri olarak, okul yöneticileri, okulu yaşatma amacı kapsamında ilgili mevzuat ve programlar çerçevesinde okulun tüm işlerini yürütmek, düzenlemek ve denetlemekle yükümlüdür (Demirtaş, Üstüner ve Özer, 2007). Bunun yanı sıra, okul yöneticileri, öğretmenler arasındaki iş birliğini teşvik etmek, farklı öğrenme fırsatları sunan kapsayıcı okullar oluşturmak, öğretmenler ve öğrenciler açısından ortaya çıkan sorunları çözümlemek gibi çok sayıda zorlukla baş etmek durumundadırlar (Cobb, 2014). Okuldan, okuldaki programının yönetiminden ve okulun başarısından birinci derecede sorumlu kişiler olan okul yöneticilerinin, kendilerine yüklenen bu görevleri başarıyla yerine getirebilmeleri eğitimin niteliği açısından çok önemlidir. Bu nedenle okul yöneticilerinin mesleki yeterliliklerinin yanı sıra, sosyal ve psikolojik özellikleri üzerinde durulması gereken önemli faktörler olarak ortaya çıkmaktadır. Nitekim okul yöneticilerine yönelik yüksek beklentiler ve taleplerin liderlik etkinliği ve okul iklimi ile negatif ilişkili olan yüksek stres ve kaygıya neden olduğu bilinmektedir (Hall Reynolds ve O’Dwyer, 2008). 


\section{Kavramsal Çerçeve}

Kaygı, insanın temel duygularından biri olan korkunun daha yaygınlaşmış ve kaynağı ya da nesnesi belirgin olmayan türüdür (Özgüven, 2003). Her insanda olduğu gibi yöneticilerde de tehlikeli ve gizemli gelen her şey kaygı yaratır. Şahin’e (2011) göre yöneticiler, gerek yönetim sürecinden gerekse de iş yükünden kaynaklanan nedenlere bağlı olarak çeşitli stres ve kaygı durumları yaşamaktadırlar. Yönetici kaygısı olarak tanımlanan bu durum yöneticinin iş yerinde karşılaştığı sorunlar nedeniyle kendisine, ailesine ve diğer kişilere yeterli zaman ayıramaması; iş arkadaşları, amirleri ve çevreyle ilişkilerinde beklentileri karşılayamaması; maddi konular, sağlık problemleri, toplumsal sorunlar ve gelişmeler sonucu oluşan kaygı durumu olarak ifade edilir. Araştırmalar, bir yöneticide kaygı oluştuğunda bu durumun onu tükenmişliğe sürüklediğini buna bağlı olarak yöneticiliği bırakma, yönetimdeki diğer paydaşlarla iletişim eksikliği, olumsuz okul ortamı, sorunlarla uzun saatler uğraşma ve sonuçta aile ve arkadaşlardan uzak durmaya varan birçok soruna neden olabildiğini göstermektedir (Robbins ve Alvy, 2014). Geçtan’a (2008) göre kaygılı yöneticiler, diğer kişilerle olan ilişkilerinde aşırı duyarlı olmakta, kendini yetersiz bulmakta, kolayca çöküntüye girebilmekte, dikkatini toplayamamakta, yanlış yapmaktan korkan bir birey haline gelmekte ve dolayısıyla bir lider olarak karar vermekte zorlanmaktadır. Okul yöneticilerinin örgütsel başarıdaki kritik yeri ve önemi nedeniyle, yönetici kaygısı üzerinde en fazla durulan konulardan birini oluşturmaktadır. İlgili alanyazında yapılan çalışmaların (Feitler ve Tokar, 1986; Gemelch ve Chan, 1995; McDonald, 2016; Ok, 2006; Record, 2016; Shambrook, 2011; Şahin, 2011; Ural, 2001) daha çok okul yöneticilerinin kaygı düzeyleri ve kaygıya neden olan faktörler üzerine yoğunlaştığı görülmektedir. Bunun yanı sıra okul yöneticilerinin kaygı düzeyleri ile karar verme (Özcan, 1999), yetki devri (Özdayı, 2001), bilgisayar kaygısı (Çevik, 2006), iş doyumu (Güven ve Yalçınkaya Akyüz, 2002; Murat ve Yılmaz, 2008), kişilik özellikleri (Yaman, Bayrakçı ve Yaman, 2002), problem çözme becerileri (Esen, 2012) ilişkisine dönük çalışmaların da yapıldığı görülmektedir. Yöneticilerin kaygı düzeylerinin tespiti önemli olmakla birlikte özellikle kaygıya neden olan dışsal ve kişisel faktörlerin araştırılması ve kaygı düzeyini azaltacak çalışmaların yapılması daha fazla önem taşımaktadır. Bu noktada özellikle son yıllarda gelişen pozitif psikoloji akımının örgütsel alana yansıması olarak ortaya çıkan pozitif örgütsel davranıș (Luthans, 2002a; Luthans, 2002b; Wright, 2003; Luthans ve Youssef, 2004), alanyazında önemli bir çalışma alanı haline gelmiştir. Pozitif örgütsel davranış, çalışanların ölçülebilir pozitif psikolojik güçlerine ve özellikle de bu güçlerin sinerjik ifadesi olan psikolojik sermaye kavramına odaklanmaktadır.

Örgütsel psikolojik sermaye kavramı, genel olarak örgütsel alanda uygulanan pozitif psikolojideki kuram ve araştırmalardan ortaya çıkmıştır. Kişilerin zayıflıkları veya sorunlardan daha çok, özellikle güçlü taraflarının ortaya çıkarılması ve geliştirilmesiyle ilişkili bir kavram olarak (Seligman ve Csikszentmihalyi, 2000), insan kaynaklarının geliştirilmesi ve yönetilmesine dönük bir yaklaşımı temel almaktadır. Psikolojik sermayenin en önemli özelliği, bireyin kim olduğu ve pozitif gelişimiyle nerelere varabileceğine ilişkin cevaplar vermesidir (Luthans, Vogelgesang ve Lester, 2006; Luthans, Youssef ve Avolio, 2007). Luthans, Avolio, Avey ve Norman'a (2007) göre, psikolojik sermayeyi oluşturan unsurlar genel olarak belirlenen hedef doğrultusunda azimli 
olma (umut), mevcut zamanda ve gelecekte başarılı olunacağına dair beklentili olma (iyimserlik), yeterli çabayla zor işlerin üstesinden gelineceğine dair kendine güvenme (öz-yeterlilik), zorluklara ve sıkıntılara rağmen ayakta kalıp sonunda başarıya ulaşma (psikolojik dayanıklılık) şeklindedir.

Bireyin pozitif psikolojik gelişimsel durumu olarak da ifade edilen psikolojik sermaye (Luthans, Youssef ve Avolio, 2007) ve onun bileşenleri olan umut, iyimserlik, dayanıklllık ve özgüven, sinerjik bir etki yaratarak bir üst yapı oluşturmakta ve örgütsel çıktıları tek tek olduklarından daha olumlu şekilde etkilemektedir (Luthans ve diğ., 2007; Luthans, Avey, Avolio ve Peterson, 2010). Luthans Youssef ve Avolio’ya (2007) göre, psikolojik sermaye bileşenleri arasındaki etkileşim şu şekilde gerçekleşmektedir: Hedefe ulaşma konusunda plan yapan ve yaptığı planların kendilerini hedefe ulaştıracağını umut eden bireyler, karşılaştıkları zorlukların üstesinden gelme noktasında daha fazla motive olacaklar ve psikolojik dayanıklllık göstereceklerdir. Hedefe ulaşma konusunda kendilerine güvenen insanlar; umutlu ve iyimser yapıları ile dayanıklılıklarını, yaşamlarındaki diğer alanlara da transfer edebilecek ve uygulayabileceklerdir. Zorluklar karşısında psikolojik dayanıklılı̆̆ yüksek kişiler ise olaylara iyimser açıdan bakmak için gerekli uyum mekanizmalarını kullanmada daha becerikli olacaklardır. Psikolojik sermaye bileşenleri olan özgüven, umut ve dayanıklılık, sırasıyla kontrollü içselleştirilmiş durum algıları yoluyla iyimser bir yaklaşım tarzının gelişmesine katkı yapabilir. Bu nedenle bu konuda yapılan araştırmalar, bireysel yaratıcılık ve bilgelik, işe bağlllık, mizah, öz-yeterlik, iyimserlik, umut, psikolojik dayanıklılık ve diğer pozitif kişisel özelliklerin, örgütün çalışanlarından beklentilerini karşılama veya yüksek performansı teşvik etmedeki rollerine odaklanmıştır (Bakker, Demerouti ve Schaufeli, 2003). Nitekim yapılan çalışmalarda, çalışanların psikolojik sermayelerinin performansları ile anlamlı ve olumlu şekilde ilişkili olduğu belirtilmektedir (Luthans, Avolio, Walumbwa ve Li, 2005; Luthans ve diğ., 2007; Luthans, Avey ve Patera, 2008; Luthans ve diğ., 2010; Walumbwa, Peterson, Avolio ve Hartner, 2010; Avey, Nimnitch ve Pigeon 2010; Peterson, Luthans, Avolio, Walumbwa ve Zhang, 2011, Sun, Zhao, Yang, Bin ve Fan 2012).

Örgütsel psikolojik sermayenin en önemli bileşenlerinden olan iyimserlik kişinin olumlu olayları içsel, kalıcı ve yaygın; olumsuz olayları ise dışsal, geçici ve sadece o duruma özel olarak nitelendirmesi eğilimidir (Luthans ve Youssef, 2004). Bu özellik bireylerin olumsuzluklara ve istenmeyen durumlara karşı dayanıklı kalabilmesi açısından çok önemlidir. Ancak örgütsel psikolojik sermaye kapsamındaki iyimserlik, insanların kendilerini daha iyi hissetmeleri olarak değil, daha gerçekçi ve esnek özelliklere sahip olup, olumlu duygu ve motivasyonların bir yansıması olarak ele alınmaktadır (Luthans ve diğ., 2007). Nitekim Luthans’a (2002b) göre iyimserler daha çok çalışmak için kolay motive edilmekte; daha tatminkâr ve yüksek moralli olmakta, hedeflerine ulaşmak için istekli olup engel ve zorluklar karşısında daha sabırlı davranmakta; kişisel hatalarını kendi yetersizlikleri olarak görmek yerine, bir defaya mahsus geçici sorunlar olarak kabul etmekte, psikolojik ve fizyolojik olarak kendilerini güçlü hissetme eğiliminde olmaktadırlar.

Örgütsel psikolojik sermayenin diğer bileşeni olan umut, kişinin hedefine ulaşmakta sabır göstermesi ve bunu yaparken gerektiğinde aynı sabırla rota değişiklikleri yapabilmesi anlamına gelmektedir (Luthans ve Avolio, 2009). Erkmen ve Esen’e (2012) göre umut düzeyi yüksek olan çalışanlar, hedeflerine ulaşmak için çeşitli alternatif yollar bulabilir ve bu durum da onların 
olumsuz duygularının bastırılıp olumlu duygularının ön plana çıkmasını sağlar. Luthans ve Youssef (2004) örgütsel psikolojik sermayenin diğer bileşeni olan öz-yeterliğin; örgütsel etkinlik, örgütsel bağllık, iş doyumu, işte kalma gibi istenen davranışsal çıktılar üzerinde anlamlı bir etkiye sahip olduğunu belirtmiştir. Örgütsel psikolojik sermaye açısından diğer bileşen olan psikolojik dayanıklılık ise karşılaşılan olumsuz olaylar, bu olayların süreç ve sorumlulukları neticesinde ortaya çıkan sıkıntılar karşısında kendini toparlayabilmek olarak ele alınmaktadır. Psikolojik dayanıklılığı yüksek olan bireyler, olumsuz şartlarla karşılaştıklarında kendi ruh hallerine dönebilen ve her zaman kendileri olabilen insanlardır (Luthans ve diğ., 2007).

Psikolojik sermayenin diğer bir özelliği geliştirilebilir (Luthans, Youssef ve Avolio, 2007; Luthans ve diğ., 2010) olması ve bunun performanstaki artışı pozitif etkilemesidir. Psikolojik sermayenin geliştirilebilir olma özelliği, onu göreli olarak geliştirilebilir kişilik yapılarından (trait-like) ayırmaktadır. Yapılan bir araştırmada elde edilen bulgular, psikolojik sermayenin (0.52) pozitif duygusal durumlardan (0.46) daha fazla ölçme sabitliğine sahip olduğunu, kişilik ya da öz değerleme (0.87) özellikleri kadar ise sabit bir nitelik taşımadığını göstermiştir (Luthans, Youssef ve Avolio, 2007).

İlgili alanyazına dayalı olarak stresli bir iş yapan okul yöneticilerinin yaşadıkları kaygı düzeyleri ile psikolojik sermaye düzeyleri arasında bir ilişki olduğu düşünülmektedir. Buradan hareketle okul yöneticileri üzerinde yürütülen bu çalışmada olumsuz ve istenmeyen bir özellik olan yönetici kaygısı ile bireylerin iş performanslarını olumlu yönde etkileyen örgütsel psikolojik sermaye bileşenleri olan umut, iyimserlik, psikolojik dayanıkllık ve özyeterlik arasındaki ilişkinin ortaya çıkarılması amaçlanmıştır. Bunun yanı sıra örgütsel psikolojik sermayenin okul yöneticilerinin yönetim kaygılarını ne düzeyde yordadığı tespit edilmeye çalışılmıştır. Okul yöneticilerinin okulun niteliğini arttırmadaki rolü ve örgütsel psikolojik sermaye bileşenlerinin geliştirilebilir olması özelliği göz önüne alındığında bu çalışmadan elde edilecek bulguların özellikle yöneticilerin niteliklerini arttırmaya yönelik yapılacak uygulamalara önemli katkılar sağlayacağı düşünülmektedir.

\section{Yöntem}

$\mathrm{Bu}$ çalışmada okul yöneticilerinin psikolojik sermayelerinin yönetici kaygı düzeylerinin anlamlı bir yordayıcısı olup olmadığını test etmek amaçlandığından, araştırmanın metodu ilişkisel tarama modeli olarak belirlenmiştir. Çalışmada örgütsel psikolojik sermaye bağımsız değişken, yönetici kaygı düzeyi ise bağımlı değişken olarak alınmıştır.

\section{Evren ve Örneklem}

Araştırmanın çalışma evreni 2016-2017 eğitim öğretim yllı içerisinde İstanbul'da MEB’e bağlı okullarda yöneticilik yapan okul yöneticileridir. Araştırmanın örneklemi ise bu yöneticiler arasından basit seçkisiz örnekleme yoluyla seçilen toplam 345 okul yöneticisinden oluşmaktadır. Araştırmaya katılan yöneticilerin \% 71’i (245 kişi) okul müdürü iken \% 29’u (100 kişi) müdür yardımcısı olarak görev yapmaktadır. Ayrıca katılımcıların \% 21,4’ü (74 kişi) kadın, \% 78,6’sı 
(271 kişi) ise erkektir. Araştırmaya katılan okul yöneticilerinin \% 45,2'si (156 kişi) ilkokullarda yöneticilik yaparken, \% 28,1'i (97 kişi) ortaokul ve \% 26,7’si ise (92 kişi) liselerde yöneticilik yapmaktadırlar.

\section{Veri Toplama Araçları}

Araştırma verilerini toplamak amacıyla "Yönetici Kaygı Ölçeği” ve "Örgütsel Psikolojik Sermaye Ölçeği” kullanılmıştır.

\section{Yönetici Kaygı Ölçeği}

Araştırmada okul yöneticilerinin yönetici kaygı düzeylerini ölçmek amacıyla Şahin (2011) tarafından geliştirilmiş olan "Yönetici Kaygı Ölçeği” kullanılmıştır. Yönetici Kaygı Ölçeği "Yönetim Süreci Kaygısı" ve İş Yükü Kaygısı" olmak üzere iki faktörden ve toplam 24 maddeden oluşmaktadır. Yöneticilerin merkez örgütü, amirleri, çevresel baskı grupları, çalışma arkadaşları, kanun ve yönetmeliklerden doğan problemler neticesinde yaşanabilecek kaygı durumunu ölçen maddelerden oluşan "Yönetim Süreci Kaygısı" alt ölçeği toplam 16 maddeden oluşmaktadır. Yoğun iş yükü nedeniyle yöneticilerin kendine, ailesine ve arkadaşlarına zaman ayıramaması, sağlık ve beslenme sorunlarına bağlı olarak oluşan kaygı durumunu ölçen "İş Yükü Kaygısı” alt ölçeği ise toplam 8 maddeden oluşmaktadır. Ayrıca ölçekteki 24 maddenin toplanması yoluyla "Yönetici Kaygısı" puanı hesaplanmaktadır. Ölçekte tersten puanlanan madde bulunmamakta olup, ölçekten alınan puanların yükselmesi yöneticideki kaygı düzeyinin yüksekliğini ifade etmektedir. Ölçekte, 0 "kesinlikle katılmıyorum", 1 "katılmıyorum", 2 "kısmen katılıorum", 3 "katılıyorum" ve 4 "kesinlikle katılıyorum" şeklinde 5'li Likert tipi derecelendirme kullanılmaktadır.

Ölçeğin güvenirliğini belirlemek için Cronbach Alfa ( $\alpha$ ) iç tutarlılık katsayısı, Sperman-Brown formülü ve Guttmann split-half değerleri hesaplanmıştır. Bu analizlerin sonuçlarına göre, ölçeğin "Yönetim Süreci Kaygısı" alt boyutu için hesaplanan Cronbach Alpha ( $\alpha$ ) iç tutarlılık katsayısı ,91 olarak bulunmuştur. “İş Yükü Kaygısı” alt boyutu için hesaplanan Cronbach Alpha ( $\alpha$ ) değeri ,80 iken ölçeğin tümü için ise Cronbach Alpha (a) değeri ,91 olarak hesaplamıştır (Şahin, 2011). $\mathrm{Bu}$ araştırma için gerçekleştirilen iç tutarlık analizinde ölçeğin bütününden kestirilen toplam güvenirlik katsayısı ,87 olarak bulunurken yönetim süreci kaygısı alt boyutu için ,87 ve iş yükü kaygısı alt boyutu için ,83 olarak hesaplanmıștır.

\section{Örgütsel Psikolojik Sermaye Ölçeği}

Okul yöneticilerinin psikolojik sermaye düzeylerini tespit etmek amacıyla Luthans, Avolio, Avey ve Norman (2007) tarafından geliştirilen ve Türkçeye uyarlaması Çetin ve Basım (2012) tarafından yapılan "Örgütsel Psikolojik Sermaye Ölçeği” kullanılmıştır. Örgütsel psikolojik sermaye ölçeği; iyimserlik, psikolojik dayanıklılık, umut ve öz yeterlilik olmak üzere dört alt boyuttan ve toplam 24 maddeden oluşmaktadır. Ölçekten alınan yüksek puanlar her bir boyuta ilişkin özelliklerin yüksek olduğuna işaret etmektedir. Çetin ve Basım (2012), Psikolojik sermaye ölçeğinin Türkiye koşullarına uyarlanma çalışmasını 
kamuda çalışan 235 alt ve orta seviye yöneticinin oluşturduğu bir grup üzerinde yapmıştır. Ölçeğin geçerlik çalışması kapsamında yapılan faktör analizi sonucunda elde edilen bulgular, ölçeğin iyimserlik, psikolojik dayanıklılık, umut ve öz yeterlilik boyutlarını içeren dört faktörlü yapıyı doğruladığını göstermiştir. Ölçeğin güvenirliği kapsamında hesaplanan alt boyutlarının güvenilirlik katsayılarının, 67 ile, 85 arasında ve test-tekrar test değerlerinin ise ,70 ile ,77 arasında değiş̧tiğini göstermiştir. Sonuçta uyarlanan psikolojik sermaye ölçeğinin güvenilir ve geçerli olduğu ortaya çıarılmıştır.

\section{Verilerin Toplanması ve Analizi}

Araştırma verilerinin toplanmasında kullanılan araçlar katılımcılara 2016 yılı Kasım-Aralık ayları içerisinde uygulanmıştır. Okul yöneticilerinin yönetim kaygıları ve örgütsel psikolojik sermaye ölçeği alt boyutları arasındaki ilişkiyi ortaya çıarmak içinde Pearson korelasyon katsayısı kullanılmıştır. Örgütsel psikolojik sermaye alt boyutları olan, iyimserlik, umut, özyeterlik ve psikolojik dayanıklılı̆̆ın yönetim kaygısını yordama düzeyini tespit etmek için doğrusal regresyon analizi tekniği kullanılmıştır. Araştırmada manidarlık düzeyi .05 olarak alınmıştır.

\section{Bulgular}

Bu bölümde araştırmada toplanan verilerin istatistiksel çözümlemeleri sonucunda elde edilen bulgular yer almıştır. Okul yöneticilerinin Örgütsel psikolojik sermaye ölçeği alt boyutlarından almış oldukları puanlar ve yöneticilik kaygısı alt boyutları ile toplam puanı arasındaki ilişkiyi belirlemek için bu puanlara uygulanan Pearson Korelasyon katsayısı sonuçları Tablo 1'de sunulmuştur.

Tablo 1

Okul Yöneticilerinin Örgütsel Psikolojik Sermaye Ölçeği Alt Boyutları Puanları ile Yönetim Kaygı Düzeyleri Arasındaki Pearson Korelasyon Değerleri ( $n=345)$

\begin{tabular}{|c|c|c|c|c|}
\hline & & $\begin{array}{c}\text { Yönetim Süreci } \\
\text { Kaygısı }\end{array}$ & İş Yükü kaygısı & Yönetim Kaygısı \\
\hline \multirow{4}{*}{ 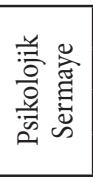 } & İyimserlik & $-.627^{* *}$ & $-.545^{\star *}$ & $-.663^{* *}$ \\
\hline & Psikolojik Dayanıklılık & $-.664^{* *}$ & $-.558^{* *}$ & $-.695^{* *}$ \\
\hline & Umut & $-.563^{* *}$ & $-.559^{* *}$ & $-.622^{* *}$ \\
\hline & Özyeterlik & $-.563^{* *}$ & $-.612^{* *}$ & $-.643^{* *}$ \\
\hline
\end{tabular}

${ }^{*} \mathrm{p}<, 05$

Tablo 1'de de görüldüğü gibi, katılımcıların örgütsel psikolojik sermayenin iyimserlik alt boyutundaki görüşleri ile yönetim süreci kaygısı ile ilgili görüşleri arasında orta düzeyde ve negatif bir ilişki $(r=-.627, p<.00)$ vardır. Buna göre okul yöneticilerinin psikolojik sermayenin 
iyimserlik boyutu ile ilgili olumlu görüşleri arttıkça yönetim süreci ile ilgili kaygıları azalmaktadır.

Tablo 1'deki korelasyon değerleri incelendiğinde yönetim süreci kaygısı, iş yükü kaygısı ve yönetim kaygısı alt boyutlarından alınan puanlar ile örgütsel psikolojik sermaye ölçeğinin alt boyutlarından alınan puanlar arasında .05 düzeyinde negatif yönlü orta düzeyde anlamlı bir ilişki olduğu görülmektedir. Bu bulgulara göre örgütsel psikolojik sermaye alt boyutları olan iyimserlik, psikolojik dayanıklılık, umut ve özyeterlik düzeyleri yükseldikçe gerek yönetim süreci kaygısı gerekse iş yükü kaygısı anlamlı düzeyde düşmektedir. Benzer şekilde örgütsel pozitif sermaye yükseldikçe okul yöneticilerinin yönetim kaygı düzeylerinde de anlamlı bir düşüş olduğu söylenebilir.

Okul yöneticilerinin, örgütsel psikolojik sermaye ölçeği alt boyutlarından almış oldukları puanların yöneticilik kaygısı toplam puanını yordama gücünü belirlemek amacıyla yapılan çoklu doğrusal regresyon analizi sonuçları Tablo 2'de verilmiştir.

Tablo 2

Okul Yöneticilerinin Psikolojik Sermaye Düzeylerinin Yönetim Kaygısı Toplam Puanını Yordamasına Ilişkin Regresyon Analizi Sonuçları

\begin{tabular}{|l|c|c|c|c|c|}
\hline \multicolumn{1}{|c|}{ Yordayıcı Değişkenler } & $\mathrm{B}$ & $\mathrm{SH}$ & $\beta$ & $\mathrm{t}$ & $\mathrm{p}$ \\
\hline Sabit & 117.481 & 2.679 & & 43.859 & .000 \\
\hline İyimserlik & -.636 & .217 & -.231 & -2.935 & .004 \\
\hline Psikolojik Dayanıklılık & -1.052 & .173 & -.415 & -6.073 & .000 \\
\hline Umut & .160 & .205 & .063 & .784 & .434 \\
\hline Özyeterlik & -.450 & .161 & -.194 & -2.787 & .006 \\
\hline \multicolumn{2}{|c|}{$\mathrm{R}=, 726$} & $\mathrm{R}^{2}=, 527$ & $\mathrm{~F}_{(4-340)}=94,821$ & $\mathrm{p}=, 001$ & \\
\hline
\end{tabular}

Tablo 2'de ki bulgular incelendiğinde, bağımsız değişkenler (yordayıcı değişkenler) olarak analize giren örgütsel psikolojik sermaye ölçeğinin, iyimserlik, psikolojik dayanıklılık, umut ve özyeterlik alt boyutlarının yönetim kaygısı toplam puanını anlamlı düzeyde yordadığı görülmektedir ( $\left.\mathrm{R}=, 726 ; \mathrm{R}^{2}=, 527 ; \mathrm{F}_{(4-340)}=94,821 ; \mathrm{p}<, 001\right)$. Bu bulgu örgütsel psikolojik sermaye ölçeğinin tüm alt boyutlarının yönetim kaygısı ölçeğinden alınan toplam puanına ilişkin varyansın \%52,7'sini açıkladığını göstermektedir. Bağımsız değişkenlere ilişkin t testi sonuçlarına göre dört bağımsız değişkenden psikolojik dayanıklılık $(\beta=-, 415)$ yönetim kaygısı toplam puanının en güçlü yordayıcısı olup, bunu iyimserlik $(\beta=-, 231)$ ve özyeterlik $(\beta=-, 194)$ izlemektedir. Umut $(\beta=, 063)$ alt boyutunun ise kendi başlarına yönetim kaygısı toplam puanını yordama oranı ,05 düzeyinde anlamlı bulunmamıştır.

Okul yöneticilerinin Örgütsel psikolojik sermaye ölçeği alt boyutlarından almış oldukları puanların yöneticilik süreci kaygısı puanını yordama gücünü belirlemek amacıyla yapılan çoklu doğrusal regresyon analizi sonuçları Tablo 3’te verilmiştir. 
Marmara Üniversitesi Atatürk Eğitim Fakültesi Eğitim Bilimleri Dergisi • Journal of Educational Sciences Yll: Ocak $2017 \cdot$ Cilt-Sayı $45 \cdot$ ISSN: I300-8889 • ss. 43-57

Tablo 3

Okul Yöneticilerinin Psikolojik Sermaye Düzeylerinin Yöneticilik Süreci Kaygısı Puanını Yordamasına ilişkin Regresyon Analizi Sonuçları

\begin{tabular}{|l|c|c|c|c|c|}
\hline \multicolumn{1}{|c|}{ Yordayıcı Değişkenler } & $\mathrm{B}$ & $\mathrm{SH}$ & $\beta$ & $\mathrm{t}$ & $\mathrm{p}$ \\
\hline Sabit & 82.181 & 2.051 & & 40.071 & .000 \\
\hline İyimserlik & -.628 & .166 & -.315 & -3.782 & .000 \\
\hline Psikolojik Dayanıklılık & -.876 & .133 & -.477 & -6.607 & .000 \\
\hline Umut & .242 & .157 & .131 & 1.544 & .124 \\
\hline Özyeterlik & -.092 & .124 & -.055 & -.742 & .458 \\
\hline \multicolumn{1}{|c|}{$\mathrm{R}=, 687$} & $\mathrm{R}^{2}=, 471$ & $\mathrm{~F}_{(4-340)}$ & 75,817 & $\mathrm{p}=, 001$ & \\
\hline
\end{tabular}

Tablo 3'deki bulgular incelendiğinde, bağımsız değişkenler (yordayıcı değişkenler) olarak analize giren örgütsel psikolojik sermaye ölçeğinin, iyimserlik, psikolojik dayanıklılık, umut ve özyeterlik alt boyutlarının yönetim kaygısı toplam puanını anlamlı düzeyde yordadığ 1 görülmektedir ( $\left.\mathrm{R}=, 687 ; \mathrm{R}^{2}=, 471 ; \mathrm{F}_{(4-340)}=75,817 ; \mathrm{p}<, 001\right)$. Bu bulgu örgütsel psikolojik sermaye ölçeğinin tüm alt boyutlarının yönetim süreci kaygısı alt ölçeğinden alınan puanına ilişkin varyansın \%47,1'ini açıkladığını göstermektedir. Bağımsız değişkenlere ilişkin t testi sonuçlarına göre dört bağımsız değişkenden psikolojik dayanıklılık ( $\beta=-, 477)$ yönetim süreci kaygısı puanının en güçlü yordayıcısı olup, bunu iyimserlik $(\beta=-, 315)$ izlemektedir. Umut $(\beta=, 131)$ ve özyeterlik $(\beta=-, 055)$ alt boyutlarının ise kendi başlarına yönetim süreci kaygısı puanını yordama oranları ,05 düzeyinde anlamlı bulunmamıştır.

Okul yöneticilerinin Örgütsel psikolojik sermaye ölçeği alt boyutlarından almış oldukları puanların iş yükü kaygısı puanını yordama gücünü belirlemek amacıyla yapılan çoklu doğrusal regresyon analizi sonuçları Tablo 4'te verilmiştir.

Tablo 4

Okul Yöneticilerinin Psikolojik Sermaye Düzeylerinin Iş Yükü Kaygısı Puanını Yordamasına Ilişkin Regresyon Analizi Sonuçları

\begin{tabular}{|l|c|c|c|c|c|}
\hline \multicolumn{1}{|c|}{ Yordayıcı Değişkenler } & $\mathrm{B}$ & $\mathrm{SH}$ & $\beta$ & $\mathrm{t}$ & $\mathrm{p}$ \\
\hline Sabit & 35.300 & 1.161 & & 30.403 & .000 \\
\hline İyimserlik & -.009 & .094 & -.008 & -.091 & .928 \\
\hline Psikolojik Dayanıklılık & -.176 & .075 & -.181 & -2.340 & .020 \\
\hline Umut & -.081 & .089 & -.083 & -.918 & .359 \\
\hline Özyeterlik & -.358 & .070 & -.402 & -5.119 & .000 \\
\hline \multicolumn{1}{|c|}{$\mathrm{R}=, 631$} & $\mathrm{R}^{2}=, 398$ & $\mathrm{~F}_{(4-340)}=56,173$ & $\mathrm{P}=, 001$ & \\
\hline
\end{tabular}

Tablo 4'teki bulgular incelendiğinde, bağımsız değişkenler (yordayıcı değişkenler) olarak analize giren örgütsel psikolojik sermaye ölçeğinin, iyimserlik, psikolojik dayanıklılık, umut 
ve özyeterlik alt boyutlarının iş yükü kaygısı toplam puanını anlamlı düzeyde yordadığı görülmektedir ( $\left.\mathrm{R}=, 631, \mathrm{R}^{2}=, 398, \mathrm{~F}_{(4-340)}=56,173, \mathrm{p}<, 001\right)$. Bu bulgu örgütsel psikolojik sermaye ölçeğinin tüm alt boyutlarının iş yükü kaygısı alt ölçeğinden alınan puanına ilişkin varyansın \%39,8'ini açıkladığını göstermektedir. Bağımsız değişkenlere ilişkin $t$ testi sonuçlarına göre dört bağımsız değişkenden özyeterlik ( $\beta=-, 402)$ yönetim süreci kaygısı puanının en güçlü yordayıcısı olup, bunu psikolojik dayanıklılık $(\beta=-, 181)$ izlemektedir. Umut $(\beta=, 083)$ ve iyimserlik $(\beta=, 008)$ alt boyutlarının ise kendi başlarına yönetim süreci kaygısı puanını yordama oranları , 05 düzeyinde anlamlı bulunmamıştır.

\section{Tartışma ve sonuç}

Okul yöneticileri üzerinde gerçekleştirilen bu araştırmanın sonuçları öncelikle psikolojik sermayenin dört boyutu (iyimserlik, psikolojik dayanıklılık, umut ve özyeterlik) ile yönetici kaygı düzeyleri (yönetim kaygısı toplam puanı, yönetim süreci kaygısı ve iş yükü kaygısı) arasında negatif yönlü anlamlı ilişkiler olduğunu göstermiştir. Diğer bir ifadeyle bu bulgular, okul yöneticilerinde örgütsel psikolojik sermayenin alt boyutları olan iyimserlik, psikolojik dayanıklılık, umut ve özyeterlik düzeyleri arttıkça yönetim süreci kaygısı, iş yükü kaygısı ve yönetici kaygısı düzeylerinin düştüğünü ortaya koymuştur. Bu bulgu ilgili literatürdeki araştırma sonuçlarıyla tutarlılık göstermektedir. Luthans, Youssef ve Avolio (2007) tarafından yapılan araştırmalarda, psikolojik dayanıklılığın mutluluk, performans, iş doyumu, örgüte bağlılık gibi pozitif özelliklerle doğrudan ilişkili olduğunu göstermiştir. Bu nedenle özellikle okul yöneticilerinin yönetim becerileri üzerinde olumsuz bir etkiye neden olan ve çevreleriyle çeşitli sorunlar yaşamalarına sebebiyet veren yönetim kaygısı ile örgütsel psikolojik sermaye arasında bu araştırmada elde edilen negatif yönlü ilişki manidar bulunmaktadır.

$\mathrm{Bu}$ araştırmanın temel amacını oluşturan okul yöneticilerinin yönetim kaygılarının yordayıcılarının belirlenmesine ilişkin bulgular psikolojik sermayenin alt boyutlarının yönetici kaygısı, yönetim süreci kaygısı ve iş yükü kaygısını anlamlı olarak yordadıklarını göstermiştir. Daha açık bir ifadeyle yönetici kaygısı toplam puanları üzerinde yapılan çoklu doğrusal regrasyon analizi sonuçları örgütsel psikolojik sermaye ölçeğinin, iyimserlik, psikolojik dayanıklılık, umut ve özyeterlik alt boyutlarının birlikte yönetim kaygısı toplam puanının \%52,7’sini açıkladığını göstermiştir. Bağımsız değişkenlerden psikolojik dayanıklılığın yönetim kaygısı toplam puanının en güçlü yordayıcısı olduğu, bunu iyimserlik ve özyeterliğin izlediği, umut değişkeninin ise yönetim kaygısı toplam puanın anlamlı bir yordayıcısı olmadığı tespit edilmiştir. Bu bulgular okul yöneticilerinin yönetici kaygılarına örgütsel psikolojik sermayenin psikolojik dayanıklılık, iyimserlik ve özyeterlik düzeylerinin birlikte \%52,7 gibi bir katkıda bulunduğuna işaret etmektedir. Benzer şekilde okul yöneticilerinin yönetim süreci kaygılarına ilişkin bulgular da örgütsel psikolojik sermaye alt boyutlarının birlikte yönetim süreci kaygısındaki varyansın \%47,1'ini açıkladığını göstermiştir. Özellikle umut ve özyeterlik hariç psikolojik dayanıklılık ve iyimserliğin yönetim süreci kaygısının anlamlı yordayıcıları olduğu görülmüştür. İş yükü kaygısı boyutuna ilişkin çoklu doğrusal regresyon analizinden elde edilen bulgular, örgütsel psikolojik 
sermayenin dört alt boyutunun birlikte iş yükü kaygısındaki varyansın \%39,8'ini açıladığını ortaya çıkarmıştır. Özellikle özyeterlik ve psikolojik dayanıklılı̆ın iş yükü kaygısının anlamlı yordayıcıları olarak katkıda bulundukları tespit edilmiştir.

Bu çalışmada beklenildiği üzere okul yöneticilerinin örgütsel psikolojik sermaye düzeylerinin yönetici kaygısının anlamlı yordayıcıları olduğu bulunmuştur. Temelde bağımlı ve bağımsız değişkenler arasındaki ilişkilerin incelendiği bu araştırmada elde edilen bu bulguların yorumlanmasında ihtiyatlı olunması gerekmektedir. Çünkü araştırmada bağımsız değişkenlerin bağımlı değişkenlere etkisi incelenmediğinden araştırmadan elde edilen bu bulgular değişkenler arasında sebep sonuç ilişkisi kurmaya olanak vermemektedir. Bu açıklamaya bağlı kalarak bu araştırmanın sonuçlarının gerek kaygı gerekse yönetici kaygısına ilişkin teorik görüşlerce desteklendiği görülmektedir. Şöyle ki; okullarda yönetimin nitelikli olması, okul yöneticilerinin sahip olmaları gereken birçok nitelikli özellik yanında, stres ve kaygı ortamından uzak olmalarını gerekli kılmaktadır. Bu açıdan mesleki yeterliliğin yanı sıra, bireylerin sahip olduğu sosyal özellikler ve psikolojik kararlılık ve sağlamlık her geçen gün daha çok önem kazanmaktadır. Yöneticinin kişisel özellikleri bu ölçütlerle örtüşmediği zaman stres ve korku oluşabilir (Esen, 2012). Köknel’e (2005) göre kaygı, dışarıdaki bir nesneden veya kişiliğin kendisinden kaynaklı oluşsa da kaygı yaratan durum karşısında, kişilik değişik süreçlerde, değişik cevaplarla durumu karşılamaktadır. Kaygıyı yaratan durumun algılanması, anlaşılması ve bilinçlenme sonrasında, kaygı yaratan durum karşısında, kişinin sergileyeceği tutum ve davranış da bilinçlidir. Ancak, kaygı karşısında bilinçdışı savunmalar da sergilenebilmektedir. Kişilik yapısına göre çeşitli savunma düzenekleri devreye girebilmekte ve bunların bir kısmı olumlu ve başarılı savunma düzenekleriyken bir kısmı da kaygıya karşı, kişilik gelişimi üzerinde olumsuz etki eden, ruh sağlı̆̆ı üzerinde olumsuz etkileri olan savunma düzenekleri olabilmektedir. Bu açıdan bu araştırmada yordayıcı değişkenler olarak ele alınan örgütsel psikolojik sermaye bileşenleri olan iyimserlik, psikolojik dayanıklılık, umut ve özyeterlik gibi kişisel özelliklerin bireylerin karşılaştıkları kaygı yaratıcı ortamlarda olumlu ve başarılı savunma düzenekleri olarak görev yaptığı elde edilen bulgulara dayalı olarak ileri sürülebilir.

$\mathrm{Bu}$ araştırma ilgili alanyazında okul yöneticilerinin örgütsel psikolojik sermayeleri ve yöneticilik kaygıları arasındaki ilişkileri inceleyen ilk araştırma olduğu için bu araştırmanın sonuçlarıyla diğer araştırmaları doğrudan karşılaştırma olanağı yoktur. Ancak örgütlerde örgüt üyelerinin sahip oldukları psikolojik sermayenin onların işlerine karşı olumlu tutumlar geliştirmelerini sağlayıcı ve olumsuz tutumlarını ise önleyeceği ya da azaltacağ (Beğenirbaş ve Turgut, 2016; Erkuş ve Findıklı, 2013; Karakuş ve Demir, 2015; Ocak, Güler ve Basım, 2016; Töremen ve Demir, 2016; Tüzün, Çetin ve Basım, 2014). Diğer taraftan Kutanis ve Oruç'a (2014) göre yapılan çalışmalar psikolojik sermaye ve bileşenlerinin performans, iş tatmini, çalışan mutluluğu, örgütsel bağllık gibi konularla ilişkili olduğunu ve bu kavramları pozitif yönde etkilediğini ortaya koymuştur. Dolayısıyla psikolojik sermaye bileşenleri ile yöneticilerin kaygı düzeyleri arasında bu araştırmada ortaya çıkan negatif yönlü ilişkiler önemli olarak görülmektedir. 
$\mathrm{Bu}$ araştırmanın sonuçlarına dayanarak okul yöneticileri üzerinde gelecekte yapılacak araştırmalara yönelik olarak şu öneriler sunulabilir: Araştırma sonuçlarına göre okul yöneticilerinin sahip oldukları psikolojik sermaye düzeyi arttıkça, psikolojik açıdan daha güçlü hale gelmekte ve iş içinde zorluklarla daha kolay mücadele edebilmekte ve iş içinde olumsuz duyguları daha az hissetmektedirler. Psikolojik sermaye bileşenlerinin ölçülebilir olmasının yanında geliştirilebilir olmaları da göz önüne alındığında okul yöneticilerinin psikolojik sermayelerini güçlendirme ve geliştirme çalışmalarının yapılması önemlidir. Diğer taraftan bu araştırmada belirlenen ilişkilerin nedenlerine yönelik farklı örneklemlerle ve farklı araştırma desenleri kullanılarak daha geniş örneklemlerle benzer araştırmalar yapılabilir. 


\section{Kaynaklar}

Avey, J. B., Nimnicht, J. L., ve Pigeon, N. G. (2010). Two field studies examining the association between positive psychological capital and employee performance. Leadership \& Organization Development Journal, 31(5), 384-401. http://doi.org/10.1108/ 01437731011056425

Bakker, A., Demerouti, E., ve Schaufeli, W. (2003). Dual processes at work in a call centre: An application of the job demands-resources model. European Journal of Work and Organizational Psychology, 12(4), 393-417. http://doi.org/10.1080/13594320344000165

Beğenirbaş, M., ve Turgut, E. (2016). Psikolojik Sermayenin Çalışanların Yenilikçi Davranışlarına ve Performanslarına Etkileri: Savunma Sektöründe Bir Araştırma. Dokuz Eylül Üniversitesi İktisadi ve İdari Bilimler Fakültesi Dergisi, 31(1), 57-93.

Bruce King, M., ve Bouchard, K. (2011). The capacity to build organizational capacity in schools. Journal of Educational Administration, 49(6), 653-669. http://doi.org/10.1108/ 09578231111174802

Cobb, C. (2014). Principals play many parts: A review of the research on school principals as special education leaders 2001-2011. International Journal of Inclusive Education, 3116(June 2015), 1-22. http://doi.org/10.1080/13603116.2014.916354

Çetin, F. ve Basım, H. N. (2012). Örgütsel psikolojik sermaye: Bir ölçek uyarlama çalışması. Amme İdaresi Dergisi, 45(1), 121-137.

Çevik, V. (2006). Eğitim yöneticileri ile yönetici adaylarının kaygı düzeyleri ile bilgisayar kaygısı düzeylerinin karşılaştırılması. Yayınlanmamış yüksek lisans tezi, Gaziosmanpaşa Üniversitesi Sosyal Bilimler Enstitüsü, Tokat.

Demirtaş, H., Üstüner, M. ve Özer, N. (2007). Okul yönetiminde karşılaşılan sorunların öğrenci ve okul ile ilgili değişkenler açısından incelenmesi. Kuram ve Uygulamada Eğitim Yönetimi, 51, 421-455.

Erkmen, T. ve Esen, E. (2012). Psikolojik sermaye konusunda 2003-2011 yıllarında yapılan çalışmaların kategorik olarak incelenmesi. Mustafa Kemal Üniversitesi Sosyal Bilimler Enstitüsü Dergisi, (9)19, 89-103.

Erkuş, A. ve Fındıklı, M. A. (2013). Psikolojik sermayenin iş tatmini, iş performansı ve işten ayrılma niyeti üzerindeki etkisine yönelik bir araştırma. İstanbul Üniversitesi Iş̧letme Fakültesi Dergisi, 42(2), 302318.

Esen, U. (2012). Okul yöneticilerinin yönetici kaygı düzeyleri ile problem çözme becerileri arasındaki ilişki. Yayımlanmamış yüksek lisans tezi, Ahi Evran Üniversitesi Sosyal Bilimler Enstitüsü, Kırşehir.

Feitler, F. C., ve Tokar, E. B. (1986). School administrators and organizational stress: matching theory, hunches and data. Journal of Educational Administration, 24(2), 254 - 271. http://doi.org/10.1108/ eb009919

Geçtan, E. (2008). Psikanaliz ve sonrası. İstanbul: Metis Yayınları.

Gmelch, W. H., ve Chan, W. (1995). Administrator stress and coping effectiveness: Implications for administrator evaluation and development. Journal of Personnel Evaluation in Education, 9(3), 275-285. http://doi.org/10.1007/BF00972642

Güven, A. ve Akyüz Yalçınkaya, M. (2002). Okul Yöneticilerinde kaygı-iş doyumu ilişkisinin incelenmesi. Eğitim Araştırmaları Dergisi, 7, 178-188.

Hall Reynolds, C., ve O'Dwyer, L. M. (2008). Examining the relationships among emotional intelligence, coping mechanisms for stress, and leadership effectiveness for middle school principals. Journal of School Leadership, 18, 472-500. 
Karakuş, M. ve Demir, S. (2015). Psikolojik sermaye ile stres, kaygı, tükenmişlik, iş doyumu ve işe sargınlık arasındaki ilişki. 2. Avrasya Eğitim Araştırmaları Kongresi (8-10 Haziran). Hacettepe Üniversitesi, Ankara.

Kozak, A. (2016). Okul yöneticilerinin yönetsel davranışlarının bazı değişkenler açısından incelenmesi. Yayımlanmamış yüksek lisans tezi, Uşak Üniversitesi Sosyal Bilimler Enstitüsü, Uşak.

Köknel, Ö. (2005). Kaygıdan mutluluğa kişilik. İstanbul: Altın Kitaplar Yayınevi.

Kutanis R. Ö. ve Oruç, E. (2014). Pozitif örgütsel davranış ve pozitif psikolojik sermaye üzerine kavramsal bir inceleme, The Journal of Happiness \& Well-Being, 2(2), 145-159

Louis, K.S., Leithwood, K., Wahlstrom, K. L. ve Anderson, S. E. (2010) Investigating the links to improved student learning: Final report of research findings. New York, NY: Wallace Foundation.

Luthans, F. (2002a). The need for and meaming of positive organizational behavior. Journal of Organizational Behavior, 23, 695-706. http://doi.org/10.1002/job.165

Luthans, F. (2002b). Positive organizational behavior: Developing and managing psychological strengths. Academy of Management Executive, 16(1), 57-72. http://doi.org/10.5465/AME.2002.6640181.

Luthans, F., ve Avolio, B. J. (2009). The "point" of positive organizational behavior. Journal of Organizational Behavior, 30, 291-307. http://doi.org/10.1002/job.589

Luthans, F., ve Youssef, C. M. (2004). Human, social, and now positive psychological capital management: Investing in people for competitive advantage. Organizational Dynamics, 33(2), 143-160. http:// doi.org/10.1016/j.orgdyn.2004.01.003

Luthans, F., Avey, J. B., ve Patera, J. L. (2008). Experimental analysis of a web-based training intervention to develop positive psychological capital. Academy of Management Learning \& Education, 7(2), 209221. http://doi.org/10.5465/AMLE.2008.32712618

Luthans, F., Avey, J. B., Avolio, B. J., ve Peterson, S. J. (2010). The development and resulting performance impact of positive psychological capital. Human Resource Development Quarterly, 21(1), 41-67. http://doi.org/10.1002/Hrdq.20034

Luthans, F., Avolio, B. J., Avey, J. B., ve Norman, S. M. (2007). Positive psychological capital: measurement and relationship with performance and satisfaction. Personnel Psychology, 60, 541-572. http://doi. org/DOI 10.1111/j.1744-6570.2007.00083.x

Luthans, F., Avolio, B. J., Walumbwa, F. O. ve Li, W. (2005). The psychological capital of chinese workers: Exploring the relationship with performance. Management and Organization Review, 1, 249-271.

Luthans, F., Vogelgesang, G. R., ve Lester, P. B. (2006). Developing the psychological capital of resiliency. Human Resource Development Review, 5(1), 25-44.

Luthans, F., Youssef, C. M., ve Avolio, B. J. (2007). Psychological capital: Developing the human competitive edge. Oxford, UK: Oxford University.

McDonald, A. L. (2016). Emotion, trust and urban school leadership: A perspective from urban high school principals. Unpublished doctoral dissertation, Mills College, ABD

Murat, M. ve Yılmaz, Z. (2008). İlköğretim okulu yöneticilerinin iş doyumları ile örgütsel stres kaynakları arasındaki ilişki. Fırat Üniversitesi Sosyal Bilimler Dergisi, 18(2), 203-222.

Ocak, M., Güler, M., ve Basım, H. N. (2016). Psikolojik Sermayenin Örgütsel Bağlllık ve İs Tatmini Tutumları Üzerine Etkisi: Bosnalı Öğretmenler Üzerine Bir Araştırma, Çankırı Karatekin Üniversitesi İktisadi ve İdari Bilimler Fakültesi Dergisi., 6(1), 113.

Ok, İ. (2006). İşstresinin ilköğretim okullarında okul yöneticileri üzerindeki etkisi. Yayınlanmamış yüksek lisans tezi, Selçuk Üniversitesi Sosyal Bilimler Enstitüsü, Konya. 
Özcan, K. (1999). Yöneticilerde karar verme ve kaygı ilişkisi. Yayınlanmamış yüksek lisans tezi, Marmara Üniversitesi Fen Bilimleri Enstitüsü, İstanbul.

Özdayı, N. (2001). Ortaöğretimde görev yapan eğitim yöneticilerinin yetki devri ile kaygı düzeyleri arasındaki ilişki. M. Ü. Atatürk Eğitim Fakültesi Eğitim Bilimleri Dergisi, 13, 151-164.

Özgüven, İ. E. (2003). Psikolojik testler. Ankara: Pdrem Yayınları.

Peterson, S. J., Luthans, F., Avolio, B. J., Walumbwa, F. O., ve Zhang, Z. (2011). Psychological capital and employee performance: A latent growth modeling approach. Personnel Psychology, 64(2), 427-450. http://doi.org/10.1111/j.1744-6570.2011.01215.x

Record, C. B. (2016). Secondary school principal stress and coping strategies. Unpublished doctoral dissertation, University of Southern Maine, ABD

Robbins, P., ve Alvy, H. (2014). The principal's companion: Strategies to lead schools for student and teacher success. Thousand Oaks, CA: Corwin.

Seligman, M. E. P., ve Csikszentmihalyi, M. (2000). Positive psychology: An introduction. American Psychologist. 55, 5-14. http://doi.org/10.1037/0003-066X.55.1.5

Shambrook, J. (2012). Comparison of stress-related factors in the 2007 and 2010 research administrator stress perception surveys (RASPerS). Journal of Research Administration, 43(2), 107-118.

Sun, T., Zhao, X. W., Yang, L. Bin, ve Fan, L. H. (2012). The impact of psychological capital on job embeddedness and job performance among nurses: A structural equation approach. Journal of Advanced Nursing, 68(1), 69-79. http://doi.org/10.1111/j.1365-2648.2011.05715.x

Şahin, C. (2011). Okul yöneticilerinin yönetici kaygı düzeylerinin çeşitli değişkenlere göre incelenmesi. Ahi Evran Üniversitesi Kırşehir Eğitim Fakültesi Dergisi, 12(4), 143-161.

Tüzün, İ. K., Çetin, F. ve Basım, H. N. (2014). The role of psychological capital and supportive organizational practices in the turnover process. METU Studies in Development, 41(2), 85-103.

Töremen, F., ve Demir, S. (2016). Sahip Oldukları Psikolojik Sermayenin Öğretmenlerin İșten Ayrılma Niyetleri Üzerindeki Etkisi, Mustafa Kemal Üniversitesi Sosyal Bilimler Enstitüsü Dergisi, 13(34), 166-179.

Ural, A. (2001). Okul müdürlerinin yönetsel stres kaynakları. Abant İzzet Baysal Üniversitesi Eğitim Fakültesi Dergisi, 2 (3), 74-84.

Walumbwa, F. O., Peterson, S. J., Avolio, B. J., ve Hartnell, C. A. (2010). An investigation of the relationships among leader and follower psychological capital, service climate, and job performance. Personnel Psychology, 63(4), 937-963. http://doi.org/10.1111/j.1744-6570.2010.01193.x

Wright, T. A. (2003). The incubator-positive organizational behavior: An idea whose time has truly come. Journal of Organizational Behavior, 24(4), 437-442. http://doi.org/10.1002/job.197

Yaman, M., Bardakçı, M. ve Yaman, Ç. (2002). Stres kaynakları ile yöneticilerin kişilik özellikleri arasındaki ilişki. Eğitim Araştırmaları Dergisi 3(9), 141-155. 
